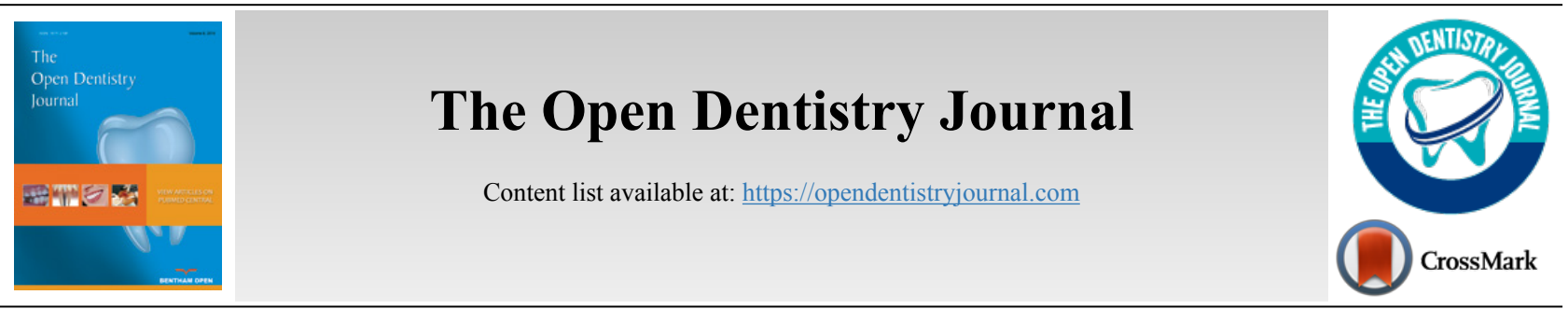

RESEARCH ARTICLE

\title{
Evaluation of the Effect of Various Powers of the Diode Laser in Microcrack Formation in the Wall of the Dental Root Canal by Scanning Electron Microscope (SEM)
}

\author{
Mostafa Godiny ${ }^{1}$, Atefeh Khavid ${ }^{2, *}$ and Morteza Jalilvand ${ }^{3}$ \\ ${ }^{1}$ Endodontics Department, Faculty of Dentistry, Kermanshah University of Medical Sciences, Kermanshah, Iran \\ ${ }^{2}$ Oral and Maxillofacial Radiology Department, Faculty of Dentistry, Kermanshah University of Medical Sciences, Kermanshah, Iran \\ ${ }^{3}$ Student Research Committee, Dental School, Kermanshah University of Medical Sciences, Kermanshah, Iran
}

\begin{abstract}
:
Background:

The laser is utilized for the removal of the smear layer, cleaning and disinfecting the dental canal. Recently, diode laser has been offered with a wavelength of (635-980nm) for cleaning and disinfecting the dental root canal.

Objective:

There is not adequate evidence for microcrack formation when using diode lasers with different powers. Therefore, the present study was conducted in order to analyze various powers of a diode laser in microcrack formation in dental root canals.

Methods:

In this experimental study, 100 mandibular incisor teeth that were extracted because of periodontal disease were selected. Using stereo-microscope, the presence of crack and fracture of the root was evaluated before and after canal instrumentation. Then, samples were randomly divided into 10 groups (10 samples in any group) based on different powers of laser and canal to be humid or dry under laser radiation. The laser was utilized for 10 s puls within three iterated times. The samples were cross-sectioned after disinfection with a diode laser at 3 and $6 \mathrm{~mm}$ length from the dental apex. Sections were observed under a scanning electron microscope and images were taken.

Results:

The frequency of microcracks is increased at the distance of (3-6mm) from the dental apex by an increase in laser power level from 2 to $4 \mathrm{w}$ $(\mathrm{P}<0.05)$. Similarly, results showed that the probability of microcrack formation under dry condition than the humid condition at the distance of $3 \mathrm{~mm}$ from the dental apex might increase to 6.606 times and at the distance of $6 \mathrm{~mm}$ from the dental apex increase to 4.978 times more.

\section{Conclusion:}

The optimal power of diode laser in the wavelength of $(980 \mathrm{~nm})$ for cleaning and disinfecting of the root canal with the minimum damage on hard periodontium tissue is $1.5 \mathrm{w}$.
\end{abstract}

Keywords: Dentin, Microcrack, Root canal treatment, Diode Laser, Scanning Electron Microscope, Dental apex.

\section{Article History} Received: May 6, 2020 Revised: August 5, 2020 Accepted: August 8, 2020

\section{INTRODUCTION}

In recent years, various lasers have been introduced for applications in dentistry, such as in accelerating orthodontic tooth movement and for the Treatment of Lateral Periodontal

\footnotetext{
* Address correspondence to this author at the Oral and Maxillofacial Radiology Department, Faculty of Dentistry, Kermanshah University of Medical Sciences, Kermanshah, Iran; Tel: 00989188362065; E-mail: atefehkhavid@gmail.com
}

Cysts $[1,2]$. One of these applications is the use of laser in the dental root canal. The main objective of dental root canal preparation is the removal of microorganisms, smear layer, and canal enlargement that enables canal filling material to reach to the end of the root [3]. The laser is utilized for the removal of the smear layer, cleaning and disinfecting the dental canal [4 6]. Recently, diode laser has been offered with a wavelength of $(635-980 \mathrm{~nm})$ for cleaning and disinfecting the dental root canal 
[7]. The application of diode laser in root canal treatment is an increase because of its disinfection property [8].

A vertical root fracture is one of the complications in dental root canal treatment that has a poor prognosis and leads to tooth extraction or cutting dental root $[9,10]$. Findings of a study done by Yamazaki et al. have shown that using Er-Cr: YSGG laser for disinfection in dry root canal causes microcrack [11]. Nevertheless, there is no adequate evidence for microcrack formation during using diode lasers with different powers. Similarly, the findings of another study indicated that any diode laser might create small thermal changes at the external root surface, although water temperature might rise up to $30^{\circ} \mathrm{C}$ during the utilization of laser, the temperature of the external root surface would finally rise $4^{\circ} \mathrm{C}$ higher. Thus, using this laser will not lead to an adverse thermal effect on dentin [12]. Likewise, the results of a study by Ribeiro et al. showed that an increase in temperature caused by diode laser did not exceed the safety limit and did not damage periodontium. SEM analysis indicated melting in Groups 2 and 3 compared to the control group in the dental apical region. Generally, diode laser may be used for root canal treatment according to the measurement parameters [13].

Given the mentioned issues, there is not adequate evidence for microcrack formation when using diode lasers with different powers. Therefore, the present study was conducted in order to analyze various powers of a diode laser in microcrack formation in dental root canals for cleaning and disinfection of root canal with the minimum damage in hard tissue surrounding the root. The null hypothesis stated the inability of laser in disinfecting the root canal.

\section{MATERIALS AND METHODS}

This study was an in vitro experimental research. In this study, the samples were selected and were divided randomized into 10 sampled groups. The inclusion criteria were mandibular incisor teeth that extracted because of periodontal disease and the presence of at least 10 samples in each group, therefore the total sample size was 100 teeth. Teeth were kept in distilled water during the study period. To ensure from teeth to be a single root canal, mesiodistal and buccolingual angles radiographic images from teeth were taken. The exclusion criteria were open apex teeth, teeth with the curved canal, multi-canal teeth, and teeth with decayed root, teeth with the calcified canal, teeth with internal and external root resorption and teeth with cracks along the root. Decoronization of singlecanal teeth was done under water cooling with a low-speed diamond disk, maintaining $16 \mathrm{~mm}$ from the apex.

Using a stereomicroscope (Olympus BX43; Olympus Co, Tokyo, Japan) at X25 magnification, the presence of crack and fracture of the root was observed for any sample. The cementum layer of the root was covered with silicon impression material as periodontal ligament space and then all roots were placed in acrylic blocks [14]. Patency and working length from the anatomic foramen of each canal was done with file NO\#8 (Dentsply Maillefer, Ballaigues, Switzerland). The final working length was determined by decreasing $1 \mathrm{~mm}$ of working length. Rubber stop, to prevent from motion, was fixed with composite resin.

Before canal instrumentation, all canals were filing by manual file (k-file) NO\#8 and 10, to create a glide path. The canal was irrigated with sodium hypochlorite $(2.5 \%)$ interval of using any tool. Then the canal of teeth was prepared by the crown-down technique with M-two file rotary system Mtwo rotary files (VDW, Munich, Germany) up to No 30 with taper $4 \%$. Using stereo-microscope at X25 magnification, the presence of crack and fracture of the root was evaluated for the second time. Then, samples were randomly divided into 10 groups based on different powers of laser and canal to be humid or dry under laser radiation (Table 1). The Diode laser (Quick lase 12W dual plus 810+980, UK) was put on the dental apex practically and pulled toward the dental crown in spiral motion. The laser was utilized for 10 s puls within three iterated times. The rest time between the use of the laser was $10 \mathrm{~s}$. The samples were cross-sectioned after disinfection with a diode laser at 3 and $6 \mathrm{~mm}$ length from the dental apex under water cooling with a low-speed diamond disk. Sections were observed under a scanning electron microscope (Jeol JSM $6500 \mathrm{~F}$, Jeol Ltd., Tokyo, Japan) at X500 magnification and images were taken.

In the current study, the samples were visually evaluated for the presence of microcracks by scanning electron microscope and stereomicroscope (Figs. 1-8). The reliability of these steps was approved by 2 specialist observers. Data analysis was done in the present research in two parts, including the descriptive and inferential statistics. The criteria

Table 1. Classification of samples based on various powers of laser and humid or dry canal upon laser radiation.

\begin{tabular}{|c|c|}
\hline Group & Description \\
\hline First group & Control group, humid canal $(\mathrm{N}=10)$ \\
\hline Second group & Control group, dry canal $(\mathrm{N}=10)$ \\
\hline Third group & Disinfection of humid canal by diode laser with power $1.5 \mathrm{~W}(\mathrm{~N}=10)$ \\
\hline Fourth group & Disinfection of dry canal by diode laser with power $1.5 \mathrm{~W}(\mathrm{~N}=10)$ \\
\hline Fifth group & Disinfection of humid canal by diode laser with power $2 \mathrm{~W}(\mathrm{~N}=10)$ \\
\hline Sixth group & Disinfection of dry canal by diode laser with power $2 \mathrm{~W}(\mathrm{~N}=10)$ \\
\hline Seventh group & Disinfection of humid canal by diode laser with power $3 \mathrm{~W}(\mathrm{~N}=10)$ \\
\hline Eighth group & Disinfection of dry canal by diode laser with power $3 \mathrm{~W}(\mathrm{~N}=10)$ \\
\hline Ninth group & Disinfection of humid canal by diode laser with power $4 \mathrm{~W}(\mathrm{~N}=10)$ \\
\hline Tenth group & Disinfection of dry canal by diode laser with power $4 \mathrm{~W}(\mathrm{~N}=10)$ \\
\hline
\end{tabular}


of centralization tendency and distribution criteria were reported with tables and diagrams in the descriptive statistical phase. The multiple-logistic regression was employed in inferential statistics to determine the relationship between variables of humidity and laser power with a variable of microcrack formation. SPSS software Version 18.0 (Inc. Chicago, IL, USA) was utilized for data analysis. The significance level was considered 0.05 in this study.

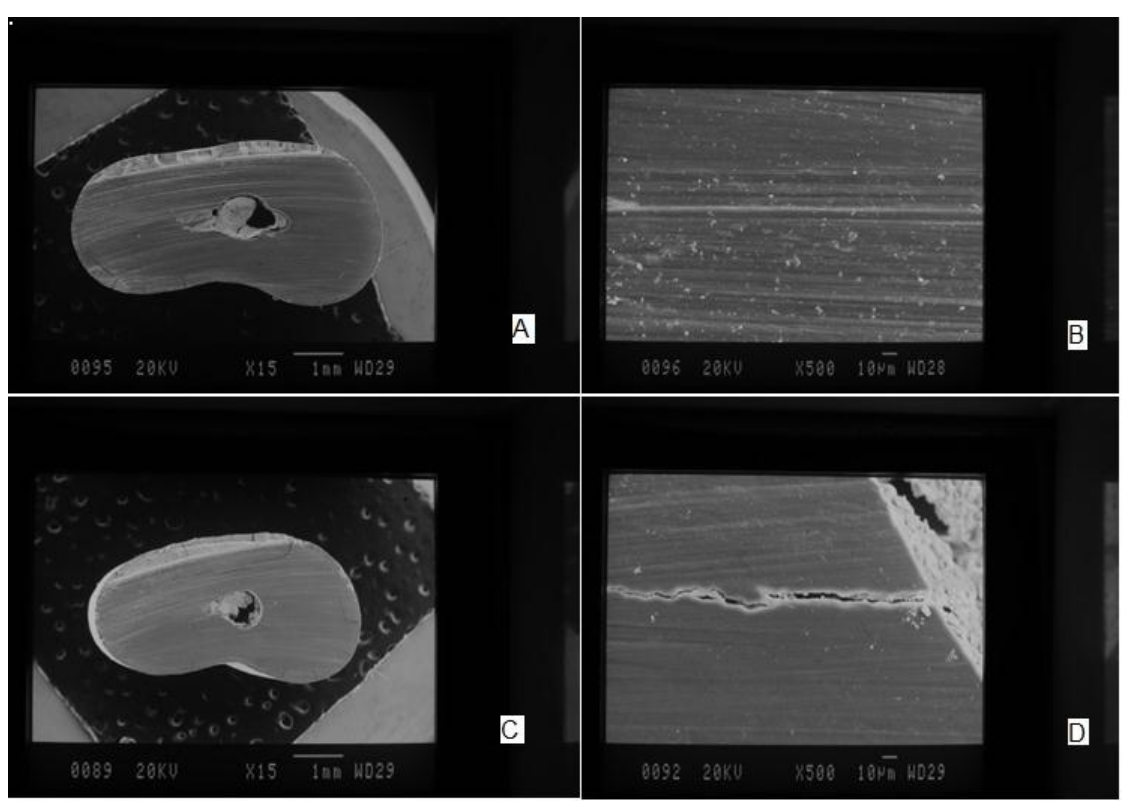

Fig. (1). The image resulting from a Scanning electron microscope for a group that disinfect the dry canal by a diode laser with power $1.5 \mathrm{~W}$; A: before laser radiation (magnitude: x15), B: before laser radiation (magnitude: x500), C: after laser radiation (magnitude: x15), D: after laser radiation (magnitude: $\times 500$ ).

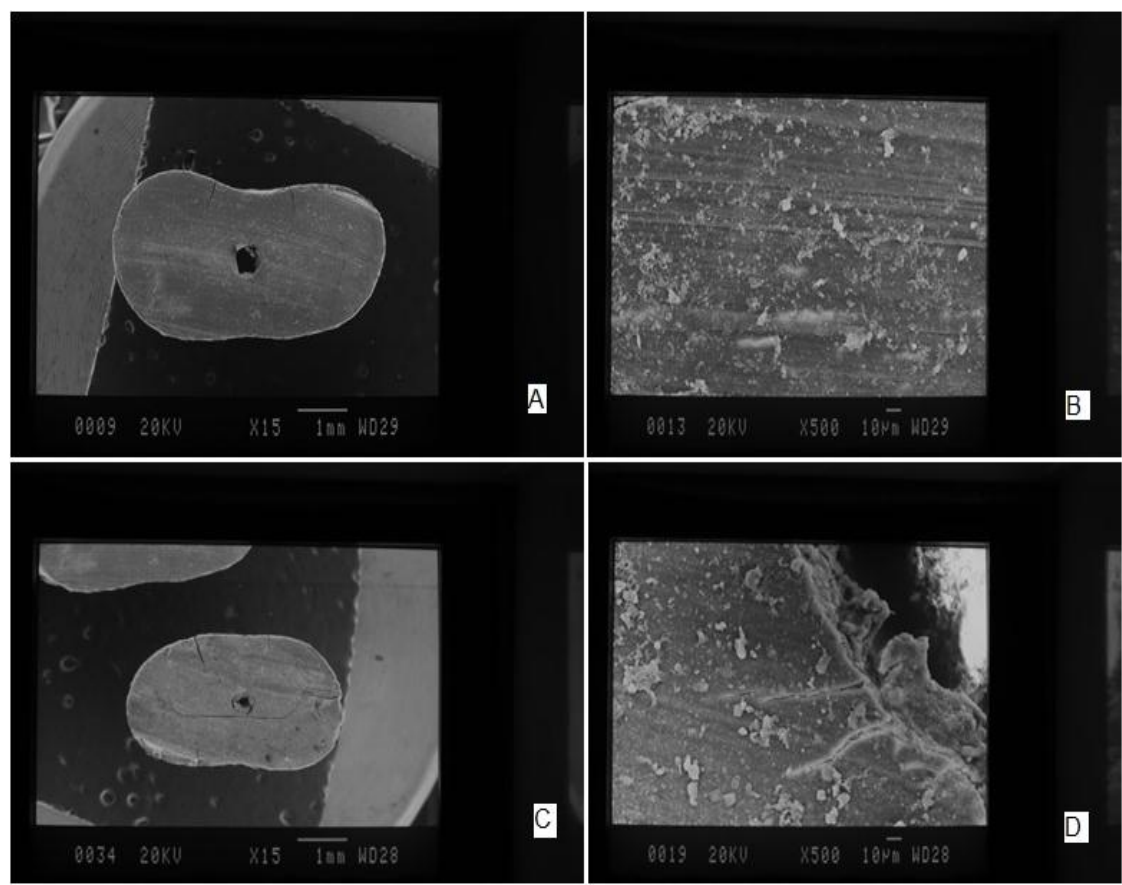

Fig. (2). The image resulting from a Scanning electron microscope for a group that disinfect the humid canal by a diode laser with power $1.5 \mathrm{~W}$; A: before laser radiation (magnitude: x15), B: before laser radiation (magnitude: x500), C: after laser radiation (magnitude: x15), D: after laser radiation (magnitude: $\times 500$ ). 


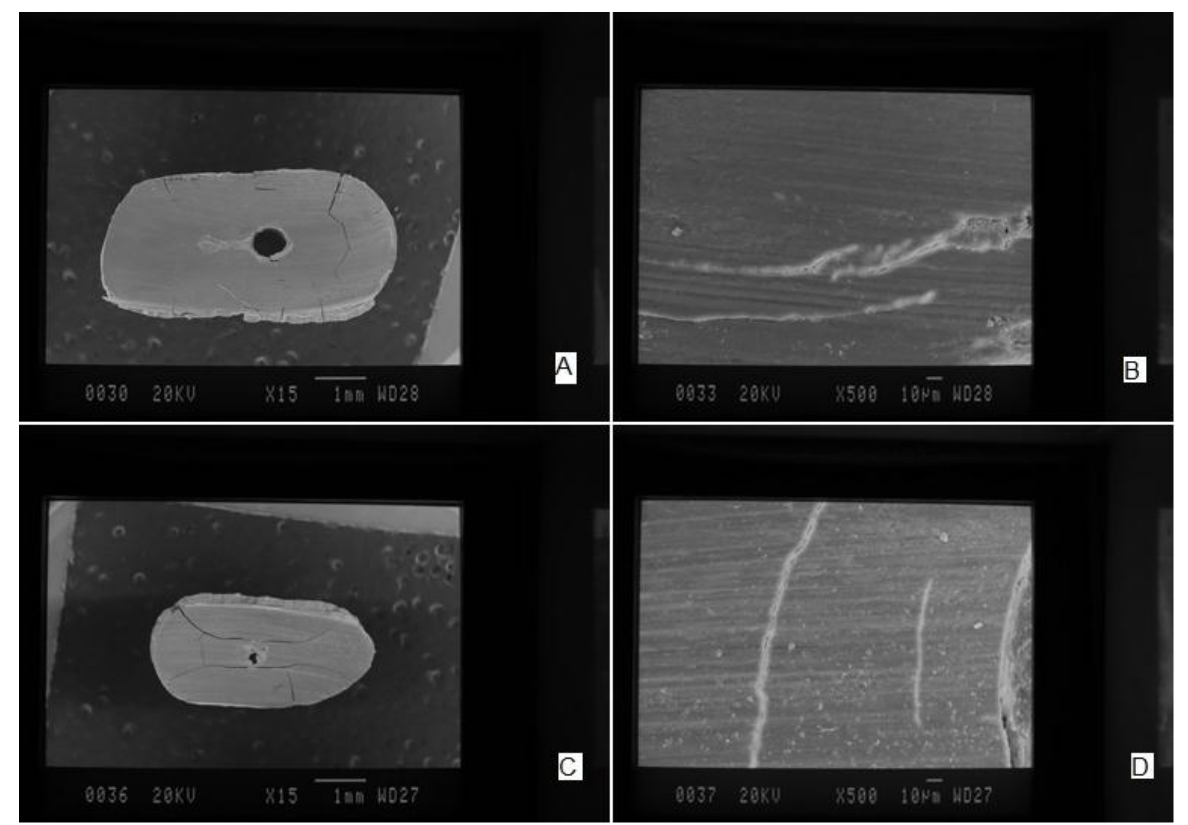

Fig. (3). The image resulting from a Scanning electron microscope for a group that disinfect the dry canal by a diode laser with power the order of the images edit and the photos of the power $4 \mathrm{~W}$ locate after photos of the powers $4 \mathrm{~W}$. A: before laser radiation (magnitude: $\mathrm{x} 15$ ), B: before laser radiation (magnitude: $\mathrm{x} 500$ ), C: after laser radiation (magnitude: $\mathrm{x} 15$ ), D: after laser radiation (magnitude: x500).

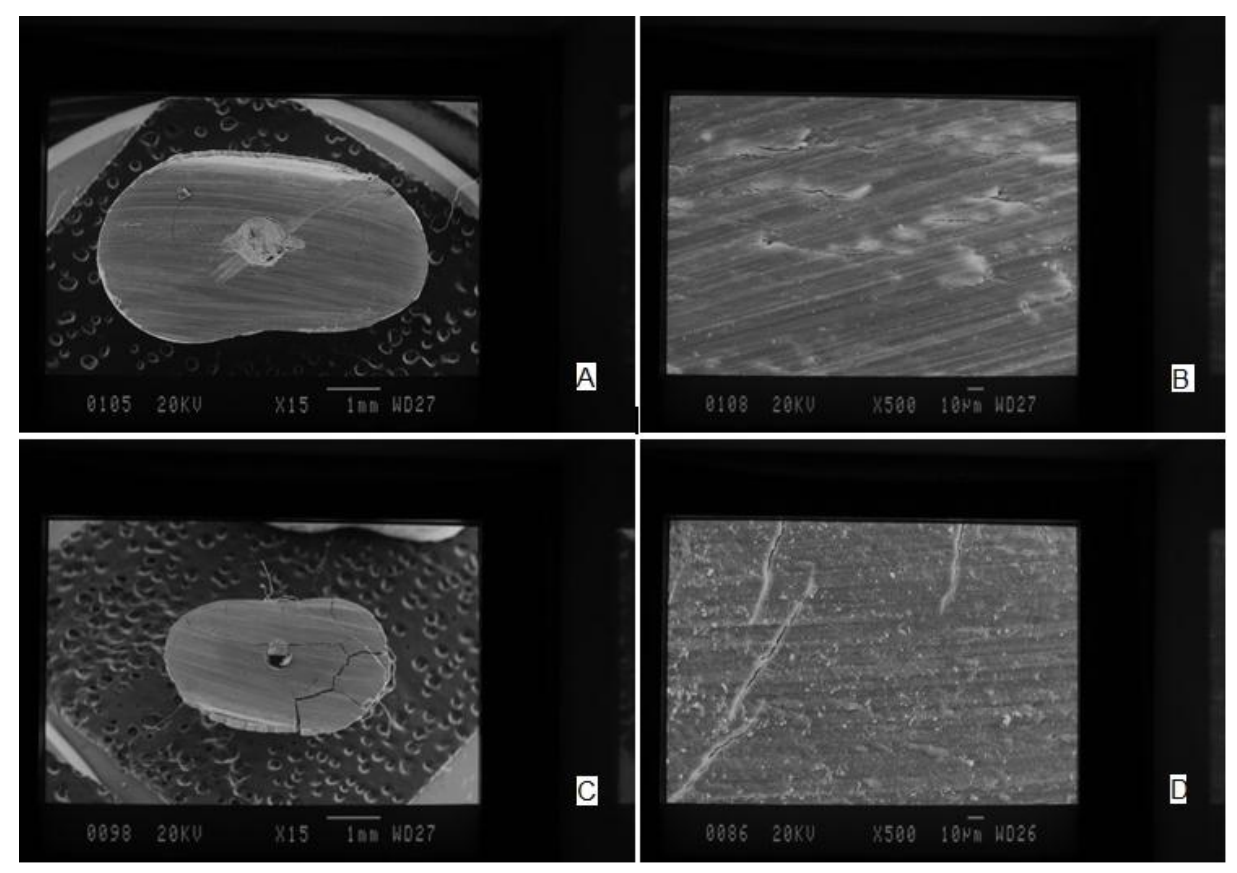

Fig. (4). The image resulting from a Scanning electron microscope for a group that disinfect the humid canal by a diode laser with power 4 W; A: before laser radiation (magnitude: x15), B: before laser radiation (magnitude: x500), C: after laser radiation (magnitude: x15), D: after laser radiation (magnitude: $\mathrm{x} 500$ ). 


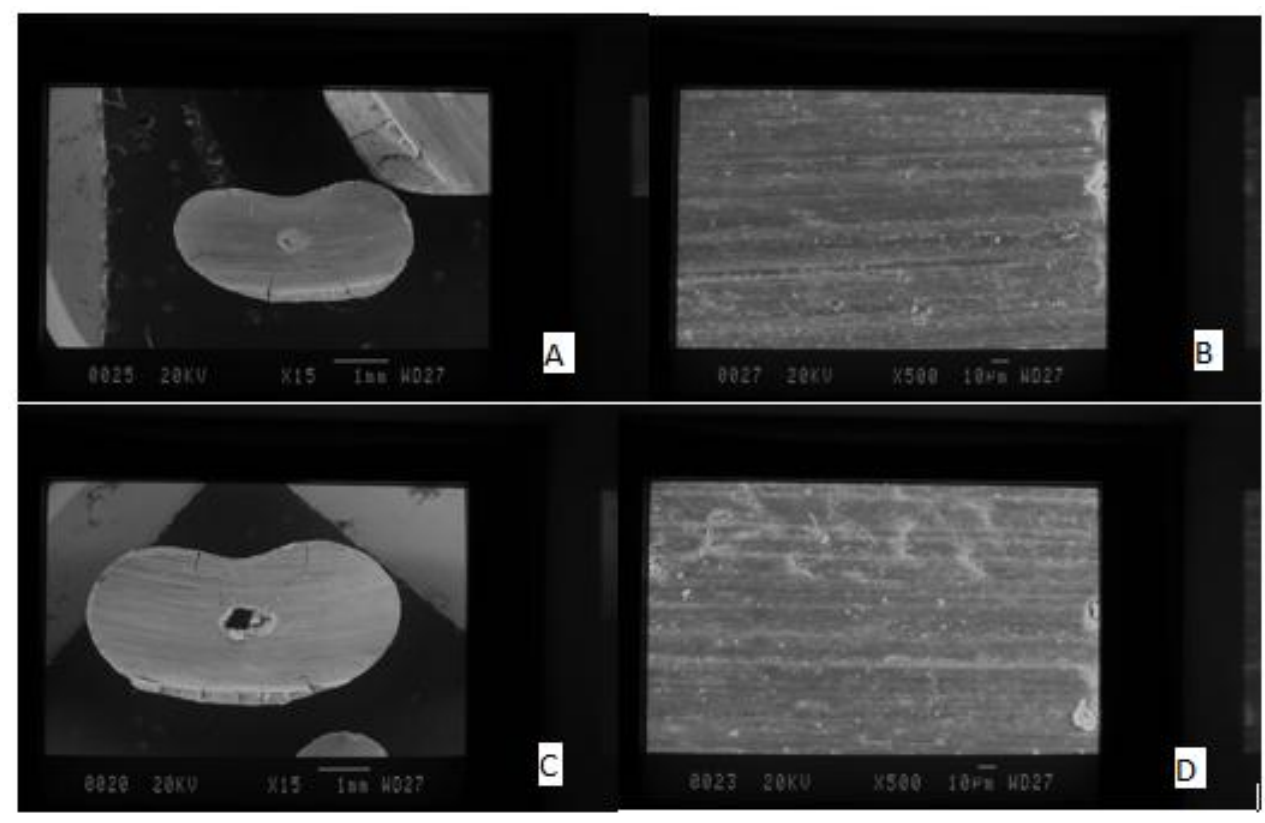

Fig. (5). The image resulting from a Scanning electron microscope for a group that disinfect the humid canal by a diode laser with power $2 \mathrm{~W}$; A: before laser radiation (magnitude: x15), B: before laser radiation (magnitude: x500), C: after laser radiation (magnitude: x15), D: after laser radiation (magnitude: $\mathrm{x} 500$ ).

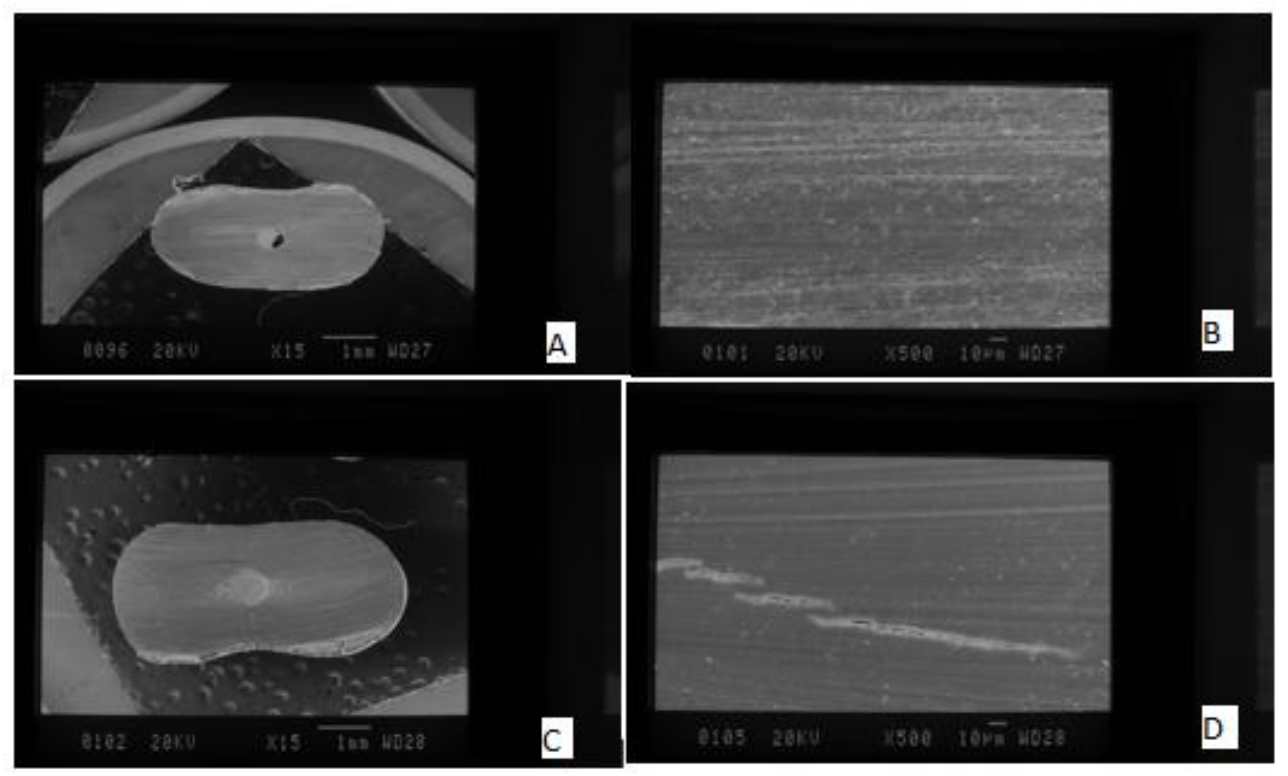

Fig. (6). The image resulting from a Scanning electron microscope for a group that disinfect the dry canal by a diode laser with power $2 \mathrm{~W}$; A: before laser radiation (magnitude: x15), B: before laser radiation (magnitude: x500), C: after laser radiation (magnitude: x15), D: after laser radiation (magnitude: $\mathrm{x} 500$ ). 


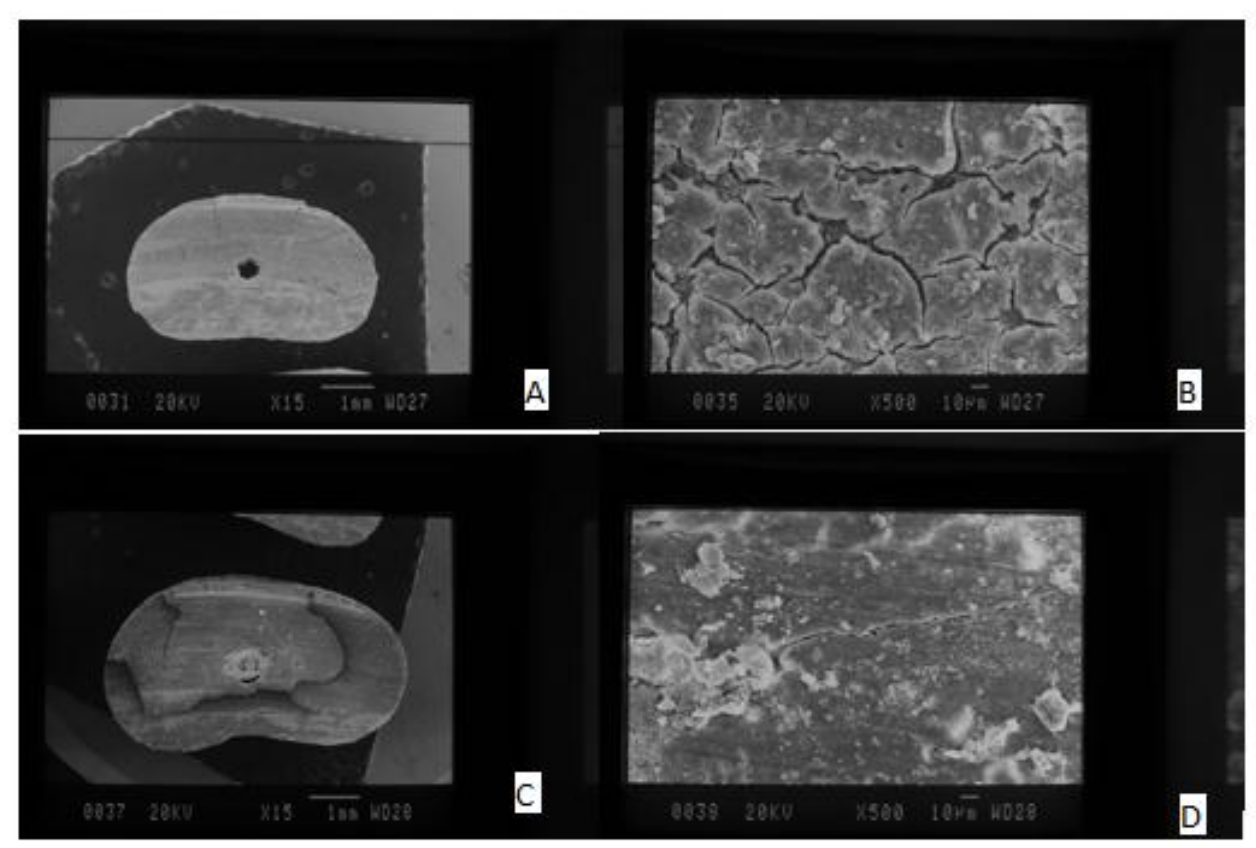

Fig. (7). The image resulting from a Scanning electron microscope for a group that disinfect the humid canal by a diode laser with power 3 W; A: before laser radiation (magnitude: x15), B: before laser radiation (magnitude: x500), C: after laser radiation (magnitude: x15), D: after laser radiation (magnitude: $\mathrm{x} 500$ ).

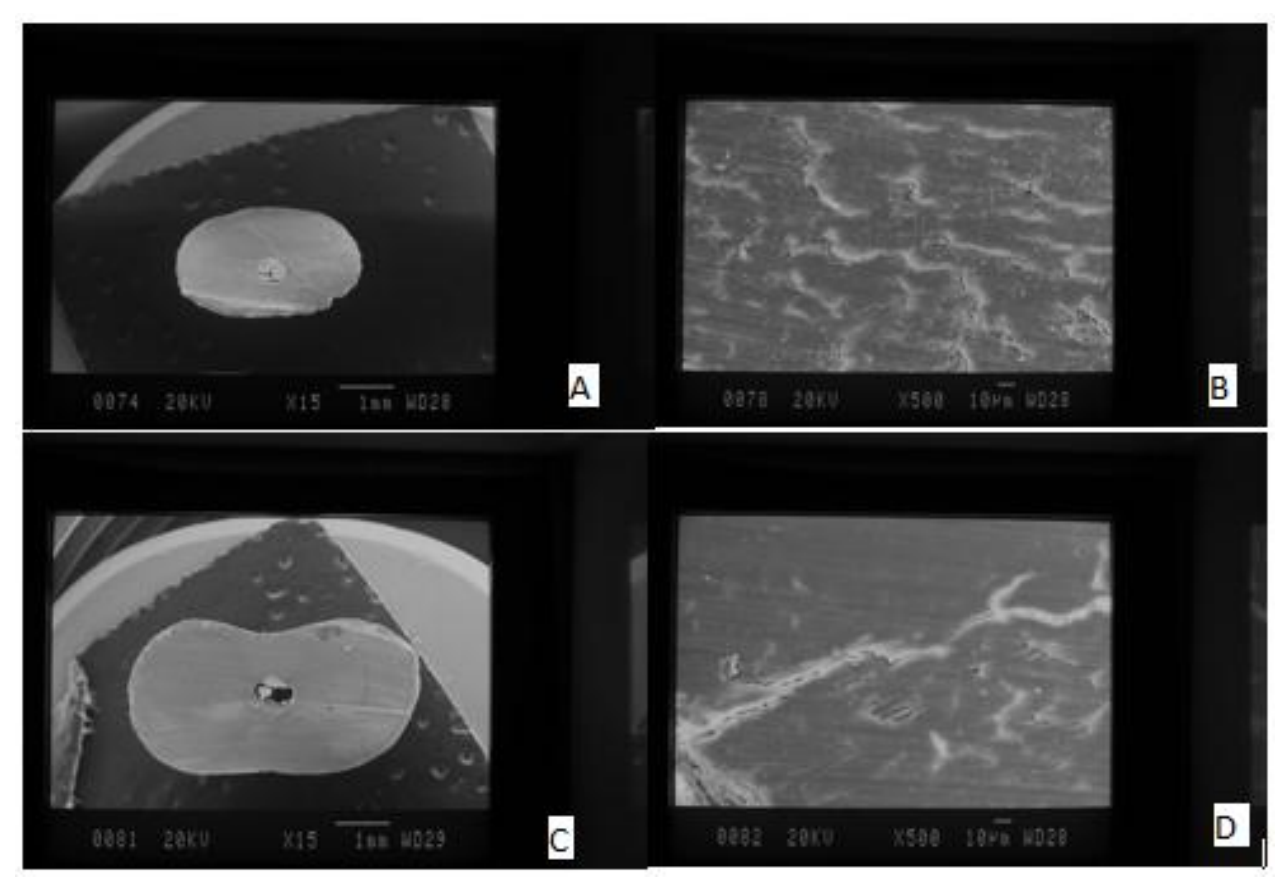

Fig. (8). The image resulting from a Scanning electron microscope for a group that disinfect the dry canal by a diode laser with power $3 \mathrm{~W}$; A: before laser radiation (magnitude: x15), B: before laser radiation (magnitude: x500), C: after laser radiation (magnitude: x15), D: after laser radiation (magnitude: $\mathrm{x} 500$ ).

\section{RESULTS}

According to Table 2, the quantity and frequency of microcracks are seen within $3 \mathrm{~mm}$ distance from dental apex separately based on laser power and humidity. The frequency of microcrack is increased by rising laser power. Similarly, the frequency of microcrack is higher under dry condition than the humid condition. According to Table $\mathbf{3}$, there was a statistically significant relationship between the probability for microcrack formation and variable of laser power so that the probability for microcrack formation at a power level of (2W) was 5.994 greater than the probability of microcrack formation without using a laser $(\mathrm{P}=0.018)$. The probability for microcrack formation with the power of ( $3 \mathrm{~W})$ was 7.867 times higher than the probability for microcrack formation when laser not used 
$(\mathrm{P}=0.008)$. The probability rate for microcrack formation by laser power $(4 \mathrm{~W})$ was 14.605 times higher than the probability for microcrack formation without the use of a laser $(\mathrm{P}=0.001)$ and only when laser used with the power of $(1.5 \mathrm{~W})$, there was no statistically significant relationship between the variable of laser power and microcrack $(\mathrm{P}=0.285)$. As shown in Table 2, the percent of microcrack formation without laser at humid condition was the same as the percentage for microcrack formation with the laser $(1.5 \mathrm{~W})$ at the humid condition. There was a statistically significant relationship between a variable of humidity and microcrack formation so that the probability for microcrack formation under dry condition was 6.606 times higher than the probability of microcrack formation at humid condition $(\mathrm{P}<0.001)$ (Table 3).

The frequency of microcrack is increased by the rise of laser power. Similarly, the frequency of microcrack is greater under dry condition than at humid condition (Table 4). There was a statistically significant relationship among probability for microcrack formation and variable of laser power so that the probability for microcrack formation in laser power of (2W) was 4.462 times higher than microcrack formation when laser not used $(\mathrm{P}=0.043)$. The probability of microcrack formation under laser power of (4W) was 17.098 times greater than of microcrack formation without the use of a laser $(\mathrm{P}=0.001)$. Only under the condition when laser power was used with power $(1.5 \mathrm{~W})$, there was no statistically significant relationship among variable of laser and microcrack $(\mathrm{P}=0.162)$. As shown in Table 3, the percent of microcrack formation without using laser under humid condition was the same as the percentage of microcrack formation by means of the laser power of $(1.5 \mathrm{~W})$ at the humid condition. There was a statistically significant relationship among the variable of humidity and microcrack formation so that the probability for microcrack formation under dry condition was 4.978 times higher than for microcrack formation at humid condition $(\mathrm{P}=0.001)$ (Table 5).

Table 2. Quantity and frequency of microcrack three millimeters distance from the dental apex separately based on laser power and humidity.

\begin{tabular}{|c|c|c|c|c|c|}
\hline \multirow{2}{*}{ Power } & - & \multicolumn{3}{|c|}{ MicroCrack 3mm } \\
\hline \multirow{2}{*}{ Moisture } & \multicolumn{3}{|c|}{ No } & Count & Row N \% \\
\cline { 3 - 6 } & & Count & Row N \% & 2 & $20.0 \%$ \\
\hline Without Laser & Yes & 8 & $80.0 \%$ & 4 & $40.0 \%$ \\
\hline- & No & 6 & $60.0 \%$ & 6 & $30.0 \%$ \\
\hline- & Total & 14 & $70.0 \%$ & 2 & $20.0 \%$ \\
\hline $1.5 \mathrm{w}$ & Yes & 8 & $80.0 \%$ & 7 & $70.0 \%$ \\
\hline- & No & 3 & $30.0 \%$ & 9 & $45.0 \%$ \\
\hline- & Total & 11 & $55.0 \%$ & 5 & $50.0 \%$ \\
\hline $2 \mathrm{w}$ & Yes & 5 & $50.0 \%$ & 8 & $80.0 \%$ \\
\hline- & No & 2 & $20.0 \%$ & 13 & $65.0 \%$ \\
\hline- & Total & 7 & $35.0 \%$ & 5 & $50.0 \%$ \\
\hline $3 \mathrm{w}$ & Yes & 5 & $50.0 \%$ & 9 & $90.0 \%$ \\
\hline- & No & 1 & $10.0 \%$ & 14 & $70.0 \%$ \\
\hline- & Total & 6 & $30.0 \%$ & 6 & $60.0 \%$ \\
\hline $4 \mathrm{w}$ & Yes & 4 & $40.0 \%$ & 10 & $100.0 \%$ \\
\hline- & No & 0 & $.0 \%$ & 16 & $80.0 \%$ \\
\hline- & Total & 4 & $20.0 \%$ & & \\
\hline
\end{tabular}

Table 3. Analysis of the relationship between variables of laser power and the presence of humidity with a variable of microcrack formation within $3 \mathrm{~mm}$ distance from the dental apex.

\begin{tabular}{|c|c|c|c|c|}
\hline \multirow{2}{*}{-} & \multirow{2}{*}{ OR } & \multicolumn{2}{|c|}{ 95\% C.I.for OR } & \multirow{2}{*}{ P-value } \\
\cline { 4 - 5 } & & Lower & Upper & \\
\hline Power & & - & - & - \\
\hline Without Laser (reference) & 1 & - & - & - \\
\hline $1.5 \mathrm{w}$ & 2.188 & .521 & 9.182 & .285 \\
\hline $2 \mathrm{w}$ & 5.994 & 1.351 & 26.593 & .018 \\
\hline $3 \mathrm{w}$ & 7.867 & 1.718 & 36.021 & .008 \\
\hline $4 \mathrm{w}$ & 14.605 & 2.872 & 74.274 & .001 \\
\hline Moisture & - & - & - & - \\
\hline Yes (reference) & 1 & - & - & - \\
\hline No & 6.606 & 2.430 & 17.955 & $<0.001$ \\
\hline
\end{tabular}


Table 4. Quantity and frequency of microcrack with $6 \mathrm{~mm}$ distance separately based on laser power and humidity.

\begin{tabular}{|c|c|c|c|c|c|}
\hline \multirow{2}{*}{ Power } & - & \multicolumn{3}{|c|}{ MicroCrack 6mm } & \multicolumn{2}{c|}{ Yes } \\
\hline \multirow{2}{*}{ Moisture } & & No & Count & Row N \% \\
\cline { 3 - 6 } & & Count & Row N \% & 3 & $30.0 \%$ \\
\hline- & Yes & 7 & $70.0 \%$ & 2 & $20.0 \%$ \\
\hline- & No & 8 & $80.0 \%$ & 5 & $25.0 \%$ \\
\hline $1.5 \mathrm{w}$ & Total & 15 & $75.0 \%$ & 3 & $30.0 \%$ \\
\hline- & Yes & 7 & $70.0 \%$ & 6 & $60.0 \%$ \\
\hline- & No & 4 & $40.0 \%$ & 9 & $45.0 \%$ \\
\hline $2 \mathrm{w}$ & Total & 11 & $55.0 \%$ & 3 & $30.0 \%$ \\
\hline- & Yes & 7 & $70.0 \%$ & 8 & $80.0 \%$ \\
\hline- & No & 2 & $20.0 \%$ & 11 & $55.0 \%$ \\
\hline $3 \mathrm{w}$ & Total & 9 & $45.0 \%$ & 4 & $40.0 \%$ \\
\hline- & Yes & 6 & $60.0 \%$ & 9 & $90.0 \%$ \\
\hline- & No & 1 & $10.0 \%$ & 13 & $65.0 \%$ \\
\hline $4 \mathrm{w}$ & Total & 7 & $35.0 \%$ & 6 & $60.0 \%$ \\
\hline- & Yes & 4 & $40.0 \%$ & 10 & $100.0 \%$ \\
\hline- & No & 0 & $.0 \%$ & 16 & $80.0 \%$ \\
\hline
\end{tabular}

Table 5. Analysis of the relationship between variables of laser power and humidity with the variable of microcrack formation within six millimeters distance from the dental apex.

\begin{tabular}{|c|c|c|c|c|}
\hline- & \multirow{2}{*}{ OR } & \multicolumn{2}{|c|}{ 95\% C.I.for OR } & \multirow{2}{*}{ P-value } \\
\hline- & & Lower & Upper & \\
\hline Power & - & - & - & \\
\hline Without Laser (reference) & 1 & - & - & - \\
\hline $1.5 \mathrm{w}$ & 2.791 & .663 & 11.756 & .162 \\
\hline $2 \mathrm{w}$ & 4.462 & 1.048 & 19.005 & .043 \\
\hline $3 w$ & 7.245 & 1.641 & 31.999 & .009 \\
\hline $4 \mathrm{w}$ & 17.098 & 3.388 & 86.297 & .001 \\
\hline Moisture & - & - & - & - \\
\hline Yes (reference) & 1 & - & - & - \\
\hline No & 4.978 & 1.935 & 12.805 & .001 \\
\hline
\end{tabular}

\section{DISCUSSION}

The effect of various powers of diode laser (with wavelength: $980 \mathrm{~nm}$ ) was examined on microcrack formation in dental wall root canals using a scanning electron microscope in the current research, thereby to identify the optimal power of diode laser for cleaning and disinfection of root canal with the minimum damage in hard tissue surrounding the root. The results of the present research showed that the frequency of microcracks increased within 3 and $6 \mathrm{~mm}$ distance from the dental apex by the rise of laser power. This increased rate was statistically significant so that following to the rise of laser power from $2 \mathrm{~W}$ to $4 \mathrm{~W}$, the probability for microcrack formation was increased 5.994 to 14.605 times within $3 \mathrm{~mm}$ distance and from 4.462 to 17.098 times within $6 \mathrm{~mm}$ distance. In this regard, Mortiz et al. also indicated that the complete removal of bacteria by diode laser only occurs if higher radiation power of the laser is used that causes higher temperature on the root surface [8]. Similarly, Esteves-Oliveira et al. radiated dentin continuously under the wavelength of $808 \mathrm{~nm}$ with a diode laser with a power of $2.5 \mathrm{~W}$, they observed initial signs of melting and structural changes in dentin [15]. In fact, while the cleaning and preparation process will be done more perfectly by an increase in laser power, this higher power may have hazardous effects on the periodontal tissue of the root canal and it may change the composition and structure of the tissue [16]. These variations may include evaporation and carbonization and even melting that is followed by recrystallization for the hard tissue [17]. Gutknecht et al. [18] implied a low rate of absorption of the diode laser in the hard tissue and expressed dominant interactions of radiation as transitional, dispersive and reflective types.

According to the wavelength $(980 \mathrm{~nm})$ of this narrow laser beam and lower power of the laser, the results of their studies are justifiable. The findings of the current study also indicated that the optimal power of $1.5 \mathrm{~W}$ for a diode laser with a wavelength of $(980 \mathrm{~nm})$ for cleaning and disinfection of root canal has minimum damage so that there was no statistically significant relationship between the variable of laser power and microcrack formation within three and six millimeter distances and the percentage of microcrack formation under humid 
condition was the same as the percent of microcrack formation at the laser power level of $(1.5 \mathrm{~W})$. In line with this finding, Asnaashari et al. showed that the power of $1.2 \mathrm{~W}$ for a diode laser with a wavelength of $810 \mathrm{~nm}$ significantly reduced all cultured species [19]. In addition, a study by Da Costa Ribeiro et al. on 24 extracted mandibular incisors concluded that despite the creation of melting in the dental apical area, a diode laser with wavelength $(810 \mathrm{~nm})$ and power $(1.25 \mathrm{~W})$ was suitable for root treatment preparation and it was not unsafe for periodontium tissue [11]. In another investigation, Wang et al. (2005) indicated that it could reduce the smear layer, which caused reducing micro-leakage of apical by using suitable power $(980 \mathrm{~nm})$ of diode laser [20].

On the other hand, water-spray on radiation site is one of the complementary activities that could be very practical along with simplicity. It may increase the disinfection effects of laser and reduce the related side-effects on hard periodontal tissue. The water presence leads to better interaction between laser and tooth, as a result, reduces thermal damage in nervous tissue and also affects the rising efficiency of the laser on dental hard tissue [21]. The studies have also shown that the diode lasers had good penetration, high interaction with water and hydroxyapatite of dental hard tissue [20,22]. Faria et al. (2013) showed that removal of the smear layer was done well in samples that had been under radiation by a diode laser at the wavelength $(980 \mathrm{~nm})$ and power $(1.5 \mathrm{~W})$ with water spray coolant and damages in dentin were limited and no fracture occurred in it [23]. The findings of the current study also indicated that dryness of the canal during laser radiation might be an influential factor for microcrack formation so that the probability for microcrack formation was increased up to 6.606 times within three millimeters distance from the dental apex and 4.978 times in six millimeters distance from the dental apex under humid condition. This shows well the impact of humidity presence on reducing the frequency of microcrack formation. The effect of water spray on reducing the frequency of microcracks in using a diode laser with wavelength $(980 \mathrm{~nm})$ may be for this reason that the wavelength in these types of lasers is adjusted to the range of water absorption in the inferred area so that dispersion and absorption of laser radiation can be ignored in other tissue elements compared to absorption of laser radiation in existing water in the given tissue. Thus, as dental enamel or dentin is radiated by a laser pulse with adequate energy, the existing water on the surface of the tissue is heated and quickly rises to the higher temperature. As a result, it destroys microorganisms on this surface to a great extent and it reduces the hazardous effects of radiation in the depth of the hard tissue [7]. Likewise, it is noteworthy that the rest time has been considered $10 \mathrm{~s}$ between any radiation interval in the present research. According to the study by Hmud et al. [12], this period was selected because of a lack of significant difference between rest times (5-15s) in operation with a diode laser at the wavelength $(980 \mathrm{~nm})$.

\section{CONCLUSION}

The optimal power of a diode laser is $1.5 \mathrm{~W}$ at the wavelength $(980 \mathrm{~nm})$ for cleaning and disinfection of the root canal at the minimum damage in the periodontal hard tissue. Likewise, the findings prove that the existing humidity may highly reduce microcrack formation within three and six millimeters distances from the dental apex and it can decrease thermal side-effects of diode lasers on dental hard tissue.

\section{SUGGESTIONS}

According to the findings of current research, it is recommended to avoid from using the higher power of $1.5 \mathrm{~W}$ in diode laser with wavelength $(980 \mathrm{~nm})$ for cleaning and disinfection of the root canal and to use certain water spray in radiation site during operational processes with a diode laser at a power level $(1.5 \mathrm{~W})$. It is also generally suggested for conducting other studies with other parameters of laser radiation as well in order to identify variables involved in laser properties further. Likewise, with respect to the rising efficiency of the laser in using along with chemical cleaning solutions in many studies, it is recommended to conduct complementary studies for further use of clinical supplementary methods. It is also suggested for the execution of future investigations about the distribution of thermal energy in the periodontal tissue of the root canal as well in order to identify the hazardous effects and controlling them better.

\section{ETHICS APPROVAL AND CONSENT TO PARTICIPATE}

The protocol of the clinical trial, was approved by the Ethics Committee of Kermanshah University of Medical Sciences, Iran.

\section{HUMAN AND ANIMAL RIGHTS}

No animals were used in this research. All human research procedures followed were in accordance with the ethical standards of the committee responsible for human experimentation (institutional and national), and with the Helsinki Declaration of 1975, as revised in 2013.

\section{CONSENT FOR PUBLICATION}

Written informed consent was obtained from each participant prior to the study.

\section{AVAILABILITY OF DATA AND MATERIALS}

The data supporting the findings of the article is available in the "jumpshare.com" at "https://jmp.sh/HyimzdQ.

\section{FUNDING}

This work was performed with funds from the Kermanshah University of Medical Sciences, Kermanshah, Iran (Grant No. 96662).

\section{CONFLICT OF INTEREST}

The authors declare no conflicts of interest, financial or otherwise.

\section{ACKNOWLEDGEMENTS}

The authors would like to acknowledge the Kermanshah University of Medical Sciences to support this work. 


\section{REFERENCES}

[1] Isola G, Matarese M, Briguglio F, et al. Effectiveness of low-level laser therapy during tooth movement: A randomized clinical trial. Materials (Basel) 2019; 12(13): 2187. [http://dx.doi.org/10.3390/ma12132187] [PMID: 31288379]

[2] Isola G, Matarese G, Lo Giudice G, et al. A new approach for the treatment of lateral periodontal cysts with an $810-\mathrm{nm}$ diode laser. Int $\mathrm{J}$ Periodontics Restorative Dent 2017; 37(1): e120-9.

[http://dx.doi.org/10.11607/prd.2981] [PMID: 27977822]

[3] Peters OA, Peters CI. Cleaning and shaping of the root canal system. Pathways of the Pulp 2006; 9: 290-357.

[4] Karlovic Z, Pezelj-Ribaric S, Miletic I, Jukic S, Grgurevic J, Anic I. Erbium:YAG laser versus ultrasonic in preparation of root-end cavities. J Endod 2005; 31(11): 821-3.

[http://dx.doi.org/10.1097/01.don.0000158234.33581.e9] [PMID: 16249727]

[5] Carvalho CA, Valera MC, Gown-Soares S, de Paula Eduardo C. Effects of Nd:YAG and Er:YAG lasers on the sealing of root canal fillings. J Clin Laser Med Surg 2002; 20(4): 215-9.

[http://dx.doi.org/10.1089/104454702760230546] [PMID: 12206724]

[6] Schoop U, Kluger W, Moritz A, Nedjelik N, Georgopoulos A, Sperr W. Bactericidal effect of different laser systems in the deep layers of dentin. Lasers Surg Med 2004; 35(2): 111-6.

[http://dx.doi.org/10.1002/1sm.20026] [PMID: 15334613]

[7] Moritz A, Beer F, Goharkhay K, Schoop U, Strassl M, Verheyen P, et al. Oral laser application. Ill: Quintessence Chicago 2006.

[8] Moritz A, Gutknecht N, Goharkhay K, Schoop U, Wernisch J, Sperr W. In vitro irradiation of infected root canals with a diode laser: Results of microbiologic, infrared spectrometric, and stain penetration examinations. Quintessence Int 1997; 28(3): 205-9. [PMID: 9452688]

[9] Lertchirakarn V, Palamara JE, Messer HH. Load and strain during lateral condensation and vertical root fracture. J Endod 1999; 25(2): 99-104.

[http://dx.doi.org/10.1016/S0099-2399(99)80005-3]

[PMID: 10204465]

[10] Tsesis I, Rosenberg E, Faivishevsky V, Kfir A, Katz M, Rosen E. Prevalence and associated periodontal status of teeth with root perforation: A retrospective study of 2,002 patients' medical records. J Endod 2010; 36(5): 797-800.

[http://dx.doi.org/10.1016/j.joen.2010.02.012] [PMID: 20416422]

[11] Yamazaki R, Goya C, Yu D-G, Kimura Y, Matsumoto K. Effects of erbium,chromium:YSGG laser irradiation on root canal walls: A scanning electron microscopic and thermographic study. J Endod 2001; 27(1): 9-12.

[http://dx.doi.org/10.1097/00004770-200101000-00003] [PMID: 11487170]
[12] Hmud R, Kahler WA, Walsh LJ. Temperature changes accompanying near infrared diode laser endodontic treatment of wet canals. J Endod 2010; 36(5): 908-11.

[http://dx.doi.org/10.1016/j.joen.2010.01.007] [PMID: 20416444]

[13] da Costa Ribeiro A, Nogueira GEC, Antoniazzi JH, Moritz A, Zezell DM. Effects of diode laser $(810 \mathrm{~nm})$ irradiation on root canal walls: thermographic and morphological studies. J Endod 2007; 33(3): 252-5. [http://dx.doi.org/10.1016/j.joen.2006.09.002] [PMID: 17320707]

[14] Priya NT, Chandrasekhar V, Anita S, et al. "Dentinal microcracks after root canal preparation" A comparative evaluation with hand, rotary and reciprocating instrumentation. J Clin Diagn Res 2014; 8(12): ZC70-2.

[http://dx.doi.org/10.7860/JCDR/2014/11437.5349] [PMID: 25654036]

[15] Esteves-Oliveira M, de Guglielmi CA, Ramalho KM, Arana-Chavez VE, de Eduardo CP. Comparison of dentin root canal permeability and morphology after irradiation with Nd:YAG, Er:YAG, and diode lasers. Lasers Med Sci 2010; 25(5): 755-60.

[http://dx.doi.org/10.1007/s10103-010-0775-z] [PMID: 20422240]

[16] Lomke MA. Clinical applications of dental lasers. Gen Dent 2009; 57(1): 47-59.

[PMID: 19146143]

[17] Gupta S, Kumar S. Lasers in dentistry-An overview. Trends Biomater Artif Organs 2011; 25(3): 119-23.

[18] Gutknecht N, Franzen R, Schippers M, Lampert F. Bactericidal effect of a 980 -nm diode laser in the root canal wall dentin of bovine teeth. J Clin Laser Med Surg 2004; 22(1): 9-13.

[http://dx.doi.org/10.1089/104454704773660912] [PMID: 15117481]

[19] Asnaashari M, Godiny M, Azari-Marhabi S, Tabatabaei FS, Barati M. Comparison of the antibacterial effect of $810 \mathrm{~nm}$ diode laser and photodynamic therapy in reducing the microbial flora of root canal in endodontic retreatment in patients with periradicular lesions. J Lasers Med Sci 2016; 7(2): 99-104.

[http://dx.doi.org/10.15171/jlms.2016.17] [PMID: 27330705]

[20] Wang X, Sun Y, Kimura Y, Kinoshita J, Ishizaki NT, Matsumoto K. Effects of diode laser irradiation on smear layer removal from root canal walls and apical leakage after obturation. Photomed Laser Surg 2005; 23(6): 575-81.

[http://dx.doi.org/10.1089/pho.2005.23.575] [PMID: 16356150]

[21] Steiner R. New laser technology and future applications. Med Laser Appl 2006; 21(2): 131-40.

[http://dx.doi.org/10.1016/j.mla.2006.03.007]

[22] Zehnder M. Root canal irrigants. J Endod 2006; 32(5): 389-98. [http://dx.doi.org/10.1016/j.joen.2005.09.014] [PMID: 16631834]

[23] Faria MIA, Sousa-Neto MD, Souza-Gabriel AE, Alfredo E, Romeo U, Silva-Sousa YTC. Effects of 980-nm diode laser on the ultrastructure and fracture resistance of dentine. Lasers Med Sci 2013; 28(1): 275-80.

[http://dx.doi.org/10.1007/s10103-012-1147-7] [PMID: 22760229]

(C) 2020 Godiny et al.

This is an open access article distributed under the terms of the Creative Commons Attribution 4.0 International Public License (CC-BY 4.0), a copy of which is available at: https://creativecommons.org/licenses/by/4.0/legalcode. This license permits unrestricted use, distribution, and reproduction in any medium, provided the original author and source are credited. 